\title{
Improving Reading Insights on Web Contents Based: A Survey on the Strategies Used by EFL Students
}

\author{
Risa Lestari \& Syahdan Syahdan \\ Universitas Lancang Kuning, Pekanbaru. Indonesia \\ risalestari021@gmail.com
}

\section{ARTICLE HISTORY \\ Received : 2019-01-18 \\ Revised : 2019-06-28 \\ Accepted : 2019-07-18}

\section{KEYWORDS}

Students strategies

Reading web content Global reading strategies Problem solving strategies Support reading strategies

\begin{abstract}
Implementing strategies of content chosen on the internet is a core aspect of achieving goals in expanding reading material. This study aims to investigate what are the strategies used by students on extending reading web content. This research is in the form of a survey at the English Department, Faculty of Teacher Training and Education, Universitas Lancang Kuning. There were 95 out of $126 \mathrm{EFL}$ students selected randomly as participants from reading class. A set of Likert-scale questionnaires, adopted from Mokhtari and Reichard (2002), was used to collect the data. It consisted of 30 questions divided into three strategies: Global Reading Strategies, Problem Solving Strategies, and Support Reading Strategies. To answer the research questions, descriptive statistics (SPSS 16) were used to analyze EFL students' strategies on extending reading web content questionnaires. The findings reveal that students' dominant strategy is the Problem Solving Strategies got from the mean score of 4.11 and a Standard Deviation of 0.98 . It can be categorized into a high level. It means that the majority of students have a homogenous strategy for extending reading web content. The study also reveals that students believe that the content on the internet somehow is the right source of learning. Therefore this study highlighted that students have implemented a reading strategy to make them easier to understand a text's contents.
\end{abstract}

\section{Introduction}

There are four skills in English Education, speaking, writing, listening, and reading. Reading is one of the skills that students need in achieving learning targets. The purpose of reading is to see students' abilities in developing insight, seeking information, the meaning of reading for interest and pleasure. The advantage of reading, we will get much information, both online and offline. One of the benefits of reading we will find a new vocabulary, the meaning of reading in the text. Therefore, we must understand the meaning of vocabulary in the reading to get valid information. Reading can be defined as a process to understand the meaning of the written text (Richards and Schmidt, 2010).

In understanding online reading skills, research is conducted on reading strategies among English learners when conducting teaching and learning in the classroom (Corio, 2003). Online reading is becoming more common for students in recent years. Students often turn to the internet before reading a book to gather information, read online for fun and study, and use online material to complete the task. Based on studies, the EFL reading strategy consists of three categories: global, problem solving, and support. The global strategy functions to manage student understanding based on determined planning when reading text. Then, problem-solving strategies are events that involve a helpful strategy when reading parts of the text that are considered problematic. Supporting strategies is a reading event that uses dictionaries, images, videos to understand the text's contents while reading. (Poole, 2010). Further, Sophisticated technology makes it easier for us to get or reach information available throughout the world. One of these technologies is the internet. Technological developments have changed the human way of thinking. The internet has entered almost every educational institution in every world (Jusoh and Abdullah, 2015). The internet is a form of wireless network that we can use to find the information needed.

Moreover, we can connect remotely with everyone worldwide and be easily accessed by all included students. However, the teacher should sort out the appropriate information, including articles provided in it. It is because some articles widespread on the internet are not worth reading, especially for students. The development of web-based English instructional materials to promote independent learning is practical and responded positively to lecturers and students. With the various supported activities and the relaxed 
learning atmosphere and delivery methods, the webbased English instructional materials effectively promote students' independent learning (Rahman \& Noni, 2018). Also, the internet is a powerful medium to upgrade students' literacy in which the Indonesian literacy rate is in a low category. Nofita, Yudar and Nursafira (2019) stated that digital technology is advancing, and the increasing sophistication of digital technology makes it easier to learn other languages using a variety of methods. To improve this, all parties should make Indonesian literacy better, like facilitating students to read content easily accessed on the web to emerge students' interest in reading content that they need. Because the world is developing rapidly into the digital era and Indonesia is also significantly affected by technological developments. In Indonesia, the number of internet users has reached 73 million people, or 295 of the population (The Jakarta Post, 2015). In everyday life in society, we find many uses and importance of the internet in supporting our daily lives. The information we get is also widely obtained through the internet and is one of the sciences. What is more, the internet can exist as a modern library for students. With the increasing importance of the internet, more and more surfing to get information from different web content available and most importantly is the need for students to learn independently and access knowledge that is not dependent on the teacher.

There are many ways to access content that is widespread on the internet in this century. We can use Google or other information search engines that Tare used to look for increasingly extensive references. It is very closely related to the development and use of internet technology for various needs, including educational needs among students who need web content provided on the internet and need broad insight to support competence. Technological processes and development over the years have significantly shaped the way languages are taught and learned (Tabatabaei \& Gui, 2011).

Moreover, students who need web content available on the internet require broad insights and support students' competencies. For that reason, the activities require many references to support their learning and learning process and insights in reading material among students. (Fountas \& Pinnell, 2012a; Leu \& Reinking, 2010 ; Guo, 2012). Fountas \& Pinnell (2012a) claim they can grow as readers as they encounter challenging texts such as those found on the internet. Also, Leu \& Reinking's (2010) research in online reading comprehension instruction has demonstrated the effectiveness of modified.

Moreover, Guo (2012) contended that authentic materials from the internet are precious because they can generate greater interest among teachers and students than traditionally structured materials. Technology and web content that is widespread on the internet will add interest and development of student reading materials by the interests of their respective reading material, such as humorous reading material. We can read articles related to comedy. Sometimes, improving abilities, such as English language skills, tend to use their references and interests in a particular field. For example, someone who likes humor articles, then he will search many sites and read articles related to humor.

As prospective teachers, students of English Education study programs should have broader insights on material related to their science and include the ability to use internet network technology to support them in facing the 21 st century where students increasingly use internet-based technology in their daily needs. Hamuddin (2016) added that since almost everyone nowadays uses technology to interact, play, and learn on a daily basis, no one can deny that ICT tools of education provide significant significance and ease the process of teaching and learning. As prospective teachers, especially for English Language Study Program students, they should have an appropriate strategy to improve reading insights. Therefore, echoing the discussion above, the researcher will investigate the strategy used by students on extending their reading material outside the Web-based class Faculty of Education and Teachers Training Universitas Lancang Kuning with highlighted the research questions "What are the strategies used by EFL students on extending reading web content Faculty of Education and Teachers Training Universitas Lancang Kuning?”

\section{Method}

\subsection{Research Design}

The study in this research was quantitative research. Creswell (2014) states that quantitative research is an approach for testing objective theories by examining the variables' relationship. This quantitative research was designed as a survey study. Survey research provides a quantitative or numeric description of trends, attitudes, or opinions of a population by studying that population sample. It is categorized as cross-sectional studies using questionnaires for data collection - with the intent of generalizing from a sample to a population (Creswell 2014).

\subsection{Research Setting and Participants}

This research was conducted from $6^{\text {th }}$ April until $28^{\text {th }}$ June 2020 in English Department, Faculty of Education and Teachers Training Universitas Lancang Kuning in Academic Year 2019/2020. This campus is located at Yos Sudarso St. KM. 8, Rumbai Pesisir, Pekanbaru, Riau. This research population was the English Department, Faculty of Education and Teachers Training in Universitas Lancang Kuning in Academic Year 2019/2020. The sample consists of 95 students from six classes which were from the second and fourth semesters. 


\subsection{The Technique of Data Collection}

In order to collect the data, the researcher used an online questionnaire that was Google From. The questionnaire consisted of 30 questions for students, divided into global reading strategies, problemsolving strategies, and support reading strategies. Also, the researcher used the Likert scale for collecting the data. It means, every item in the questionnaires consists of 5 choices, that is, "Always," "Often," "Sometimes," "Seldom," and "Never."

\subsection{Data Analysis}

The data collected were analyzed using the SPSS statistical package. A descriptive statistics analysis was carried out in order to see the mean score of students' answers. It can be seen on the chart below (Creswell 2012):

Measures of Central Tendency: Central Tendency indicates one number that summarizes the entire set of data/measurements central to the complete set. It describes the center position of any distribution for a given data set. The researcher analyzes the frequency of the data point in the distribution, describing it using a mean, median, and mode that measures the analyzed data set's most common patterns. It is the most informative description of the characteristics of any population (Sharma, 2019).

There are three central tendency measures: a) Mean: the sum of the variables' values/the total number of values; b) Median: the middle value; c) Mode: the most often occurring value.

Measures of Dispersion or Variation: This provides information about the range or spread of the values described for a variable. It analyzes the spread out of distribution that is set for a data set. For example, the measures of central tendency can give the average of a given data set. However, it cannot describe how the distribution of the data set was done. The key measures of dispersion are as follows: a) Variance indicates the dispersion of scores around the mean.

To calculate the score is easy, find the difference between the mean and the raw score for each individual, square the value for each individual, sum the squared for all individuals, and divide by the total number of individuals. b) Range: It is defined as the difference between the smallest and the immense value of the complete data set; c) Standard Deviation:
It measures the average distance between each quantity and means, which is how the set of data spreads out from the mean. A high standard deviation means that the data points are spread at more comprehensive values, whereas a low standard deviation means that the data points are close to the mean.

The measure of relative standing is statistics that describe one score relative to a group of the score. Two frequently used statistics are the percentile rank and $\mathrm{z}$ score. A percentile range of a particular score is the percentage of participants in the distribution with scores at or below a particular score. Another measure of relative standing is the standard score. A standard score ( $\mathrm{z}$ score) is a calculated score that enables a researcher to compare scores from a different scale. It involves the transformation of a raw score into a score with relative meaning.

After analyzed the data by using Descriptive Statistics, the researcher continued to analyse it by categorized them into Katz and Kahn range Likertscale (1978) as follows:

Table 1. The Range of Likert Scale

\begin{tabular}{ccc}
\hline No & Range & Category \\
$\mathbf{1}$ & $1.00-2.49$ & Low \\
$\mathbf{2}$ & $2.50-3.99$ & Moderate \\
$\mathbf{3}$ & $4.00-5.49$ & High \\
\hline
\end{tabular}

This range level is importantly used to identify the category of the scores, whether in "Low" or "Moderate," or "High," in order to know the homogeny or heterogeneous of the students' strategies on extending reading web content.

\section{Findings}

3.1 What strategies are used by students to extend their reading on EFL students' web content at the Department of English Education Universitas Lancang Kuning

3.1.1 Students reviewing reading strategies for purposes

There are three strategies subscales or factors: Global Reading Strategies, Problem-Solving Strategies, and Support Reading Strategies. 
Table 2. Global Reading Strategies

\begin{tabular}{|c|c|c|c|c|}
\hline $\begin{array}{l}\text { Number } \\
\text { of Questions }\end{array}$ & Statements & $\mathbf{N}$ & $\mathbf{M}$ & SD \\
\hline 1 & $\begin{array}{l}\text { I have a purpose in mind when I read the online } \\
\text { text on extending reading material. }\end{array}$ & & 4.44 & 0.71 \\
\hline 4 & $\begin{array}{l}\text { I review the online text, looking at length and } \\
\text { organization. }\end{array}$ & & 4.14 & 0.76 \\
\hline 5 & $\begin{array}{l}\text { I use the text's typographical features (bold, } \\
\text { italics, headings, colors, and fonts) to identify } \\
\text { relevant information. }\end{array}$ & & 3.91 & 1.00 \\
\hline 8 & $\begin{array}{l}\text { When choosing online content, I decide what } \\
\text { to read carefully and what I can choose to } \\
\text { ignore. }\end{array}$ & & 4.00 & 0.91 \\
\hline 11 & $\begin{array}{l}\text { I use the pictures and other graphics on the } \\
\text { sites to help increase my understanding. }\end{array}$ & & 3.78 & 0.88 \\
\hline 13 & $\begin{array}{l}\text { I use context clues to help me better } \\
\text { understand what I am reading online. }\end{array}$ & & 3.85 & 0.95 \\
\hline 14 & $\begin{array}{l}\text { I critically analyze and evaluate the } \\
\text { information I find in online texts }\end{array}$ & 95 & 3.72 & 1.01 \\
\hline 16 & $\begin{array}{l}\text { I check to see if I understand when I find new } \\
\text { information. }\end{array}$ & & 4.06 & 0.90 \\
\hline 17 & $\begin{array}{l}\text { I use context clues to help me better } \\
\text { understand what I am reading. }\end{array}$ & & 4.11 & 0.96 \\
\hline 23 & $\begin{array}{l}\text { I think about whether the online text fits with } \\
\text { my purpose text. }\end{array}$ & & 3.96 & 0.83 \\
\hline 24 & $\begin{array}{l}\text { I think about what I already know to help me } \\
\text { understand what I am reading online. }\end{array}$ & & 4.02 & 0.71 \\
\hline 25 & $\begin{array}{l}\text { I try to guess what the content of the text is } \\
\text { about when I read it. }\end{array}$ & & 3.49 & 1.08 \\
\hline 26 & $\begin{array}{l}\text { I take an overall view of the content to see } \\
\text { about what before reading it. }\end{array}$ & & 3.93 & 0.93 \\
\hline
\end{tabular}

Table 6 shows the data that potrays Global Reading Strategies. It shows that "I have a purpose in mind when I read the online text on extending reading material" (M=4.44) is the top of Global Reading Strategies.
On the contrary, statement "I try to guess what the content of the text is about when I read" $(\mathrm{M}=3.49)$ is the lowest Global Reading Strategies. In addition, the researcher used SPSS 16.0 to analyze the data to get the scores of descriptive statistics. The scores of it can be seen as follow:

\begin{tabular}{|ll|}
\hline Sum & $: 376.00$ \\
Mean & $: 3.95$ \\
Median & $: 3.72$ \\
Mode & $: 4.00$ \\
Variance & $: 0.166$ \\
Standard Deviation & $: 0.407$ \\
Range & $=$ Minimum: 3.00 \\
& $=$ Maximum: 5.00 \\
\hline
\end{tabular}

Based on the result of descriptive statistics above, it can be seen that generally, the strategies of students in the English Department, Universitas Lancang Kuning, Global Reading Strategies are categorized into the moderate level. In addition, the table above shows that the total of global reading strategies 376.00, mode of students' score is 4.00 , a median of students' score 3.72 , the variance of students' score is 0.166 , and for standard deviation is 0.407 The score of standard deviation means that all of the answers from respondents is same or homogenous. The average student's score is 3.95, which means that global reading strategies are categorized into Moderate. 
Therefore, it can be said that most of the students had answered all of the items in a range of often.

Table 3. Problem Solving Strategies

\begin{tabular}{|c|c|c|c|c|}
\hline $\begin{array}{l}\text { Number } \\
\text { of Questions }\end{array}$ & Statements & $\mathbf{N}$ & M & SD \\
\hline 2 & $\begin{array}{l}\text { I read slowly and carefully to be sure I } \\
\text { understand what I am reading. }\end{array}$ & & 4.31 & 0.73 \\
\hline 3 & $\begin{array}{l}\text { I try to get back on track or see the other } \\
\text { content when I lose concentration. }\end{array}$ & & 4.17 & 0.82 \\
\hline 12 & $\begin{array}{l}\text { When text challenging to get, I pay closer } \\
\text { attention to what I am reading }\end{array}$ & 95 & 4.03 & 0.92 \\
\hline 15 & $\begin{array}{l}\text { I adjust my reading speed according to what I } \\
\text { am choosing online. }\end{array}$ & & 4.09 & 0.90 \\
\hline 18 & $\begin{array}{l}\text { I try to guess the meaning of unknown words } \\
\text { or phrases. }\end{array}$ & & 4.11 & 0.85 \\
\hline 19 & $\begin{array}{l}\text { I try to picture or visualize information to } \\
\text { help me remember what I am reading. }\end{array}$ & & 4.01 & 0.91 \\
\hline 21 & $\begin{array}{l}\text { When text becomes difficult, I re-read it to } \\
\text { increase my understanding. }\end{array}$ & & 4.16 & 0.85 \\
\hline 29 & $\begin{array}{l}\text { I stop from time to time and think about what } \\
\text { content I choose. }\end{array}$ & & 4.04 & 0.98 \\
\hline
\end{tabular}

Table 7 shows the data that portrays problemsolving strategies. It shows that "I read slowly and carefully to be sure I understand what I am reading" $(\mathrm{M}=4.31)$ is the top of students get the main ideas and conclusion in a passage with scanning and skimming.
On the contrary, the statement "I try to picture or visualize information to help me remember what I am reading." ( $\mathrm{M}=4.01)$ is the lowest problem-solving strategy. Also, the researcher used SPSS 16.0 to analyze the data to get the scores of descriptive statistics. The scores of it can be seen as follow:

\begin{tabular}{ll|}
\hline Sum & $: 348.00$ \\
Mode & $: 4.00$ \\
Median & $: 4.11$ \\
Mean & $: 3.66$ \\
Variance & $: 0.311$ \\
Standard Deviation & $: 0.558$ \\
Range & $=$ Minimum: 3.00 \\
& $=$ Maximum: 5.00
\end{tabular}

Based on the result of descriptive statistics above, it can be seen that generally, the strategies of students in the English Department, Universitas Lancang Kuning, problem-solving strategies are categorized into a moderate level. In addition, the table above shows that the total of problem-solving strategies 348.00 , mode of students' score is 4.00 , the median of students' score 4.11, the variance of students' score is
0.311 , and for standard deviation is 0.558 The score of standard deviation means that all of the answers from respondents is same or homogenous. The average student's score is 3.66, which means that problem-solving strategies are categorized into Moderate. Therefore, it can be said that most of the students had answered all of the items in a range of often.

Table 4. Support Reading Strategies

\begin{tabular}{clccc}
\hline $\begin{array}{c}\text { Number } \\
\text { of Questions }\end{array}$ & Statements & M & SD \\
\hline 6 & $\begin{array}{l}\text { I print a copy of the online text that I choose } \\
\text { to write on it and make notes. }\end{array}$ & 3.65 & 0.98 \\
\hline & $\begin{array}{l}\text { I use the link to reference materials (like } \\
\text { dictionaries) to help me when I do not } \\
\text { understand what I choose. }\end{array}$ & 4.08 & 0.90 \\
\hline $\begin{array}{l}\text { I scroll up and down in the online text to } \\
\text { remember and connect information. }\end{array}$ & 4.13 & 0.85 \\
& $\begin{array}{l}\text { I paraphrase (say in my own words) what I 95 } \\
\text { read online }\end{array}$ & 3.92 & 0.87
\end{tabular}



understand what I choose. the text. to help me remember it.

Table 4 shows the data that portrays support reading strategies. It shows that "I write summaries to reflect on key ideas in the text." $(M=4.21)$ is the top of support reading strategies.

On the contrary, the statement "I take notes while reading to help me understand what I choose" $(M=3.75)$ is the lowest support reading strategy. Also, the researcher used SPSS 16.0 to analyze the data to get the scores of descriptive statistics. The scores of it can be seen as follow:

\begin{tabular}{ll|}
\hline Sum & $: 341.00$ \\
Mode & $: 4.00$ \\
Median & $: 4.00$ \\
Mean & $: 3.59$ \\
Variance & $: 0.308$ \\
Standard Deviation & $: 0.555$ \\
Range & $=$ Minimum: 3.00 \\
& $=$ Maximum: 5.00
\end{tabular}

Based on the result of descriptive statistics above, it can be seen that generally, the strategies of students in the English Department, Universitas Lancang Kuning, support reading strategies are categorized into a moderate level. Also, the table above shows that the total of support reading strategies 341.00 , mode of students' score is 4.00 , the median of students' score 4.00 , the variance of students' score is 0.308 , and for standard deviation is 0.555 The score of standard deviation means that all of the answers from respondents is same or homogenous.

Also, the average student's score is 3.59, which means that support reading strategies are categorized into Moderate. Therefore, it can be said that most of the students had answered the items in a range of often.

Table 5. The score of Mean, Standard Deviation and Grand Mean of all the questions

\begin{tabular}{|c|c|c|c|c|c|}
\hline $\begin{array}{c}\text { Number } \\
\text { of Questions }\end{array}$ & Statements & $\mathbf{N}$ & $\mathbf{M}$ & SD & $\begin{array}{l}\text { Grand } \\
\text { Mean }\end{array}$ \\
\hline \multicolumn{6}{|c|}{ Global Reading Strategies } \\
\hline 1 & $\begin{array}{l}\text { I have a purpose in mind when I read the } \\
\text { online text on extending reading material. }\end{array}$ & & 4.44 & 0.71 & \\
\hline 4 & $\begin{array}{l}\text { I review the online text, looking at length and } \\
\text { organization. }\end{array}$ & & 4.14 & 0.76 & \\
\hline 5 & $\begin{array}{l}\text { I use the typographical features of the text } \\
\text { (bold, italics, headings, colors, and fonts) to } \\
\text { identify relevant information }\end{array}$ & 95 & 3.91 & 1.00 & 3,95 \\
\hline 8 & $\begin{array}{l}\text { When choosing online content, I decide what } \\
\text { to read carefully and what I can choose to } \\
\text { ignore. }\end{array}$ & & 4.00 & 0.91 & \\
\hline 11 & $\begin{array}{l}\text { I use the pictures and other graphics on the } \\
\text { sites to help increase my understanding. }\end{array}$ & & 3.78 & 0.88 & \\
\hline 13 & $\begin{array}{l}\text { I use context clues to help me better } \\
\text { understand what I am reading online. }\end{array}$ & & 3.85 & 0.95 & \\
\hline 14 & $\begin{array}{l}\text { I critically analyze and evaluate the } \\
\text { information I find in online texts. }\end{array}$ & & 3.72 & 1.01 & \\
\hline 16 & $\begin{array}{l}\text { I check to see if I understand when I find new } \\
\text { information. }\end{array}$ & & 4.06 & 0.90 & \\
\hline 17 & $\begin{array}{l}\text { I use context clues to help me better } \\
\text { understand what I am reading. }\end{array}$ & & 4.11 & 0.96 & \\
\hline
\end{tabular}



my purpose text.

24 I think about what I already know to help me understand what I am reading online.

25 I try to guess what the content of the text is about when I read it.

26 I take an overall view of the content to see

$3.93 \quad 0.93$ about what before reading it.

\section{Problem Solving Strategies}

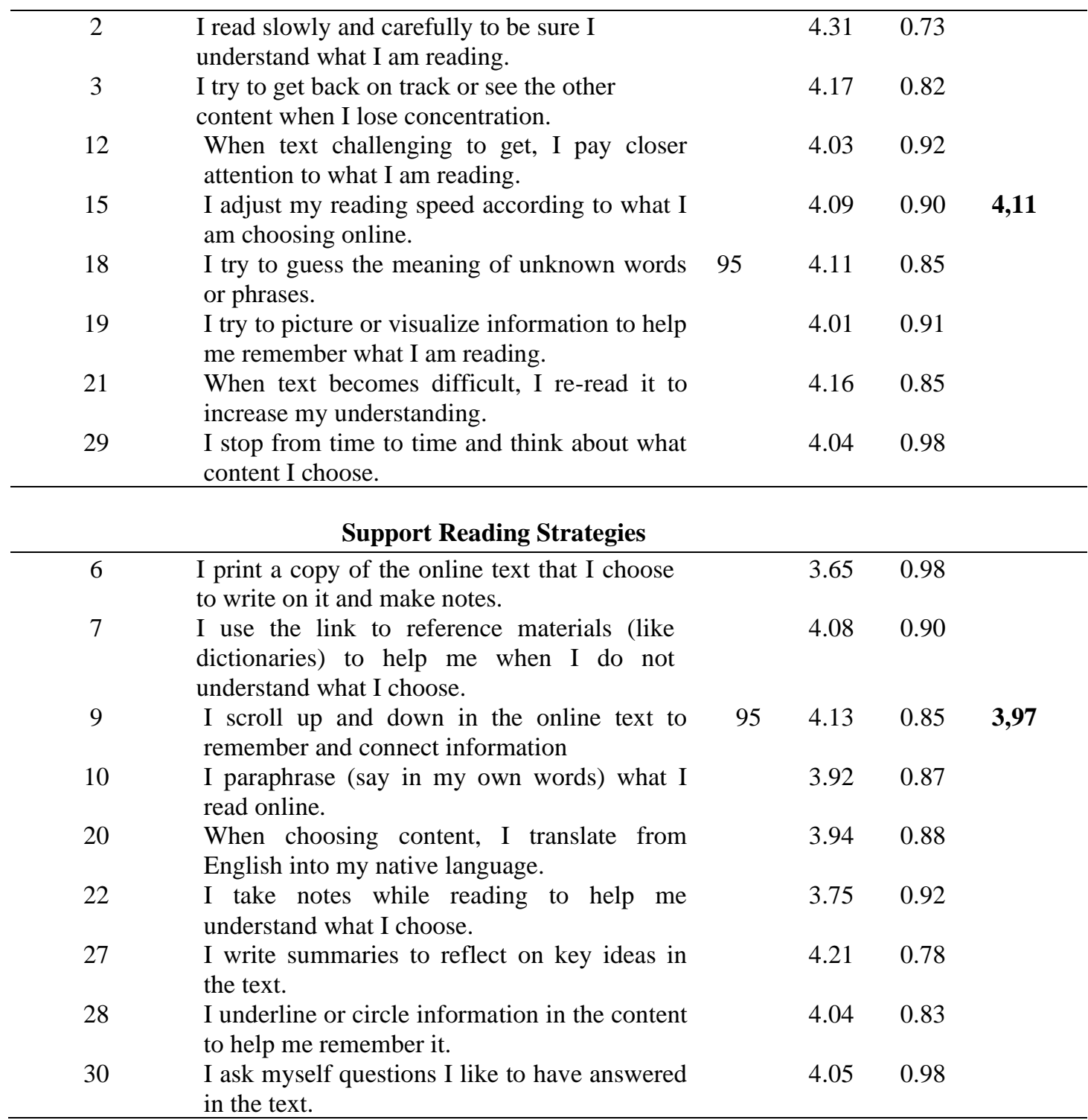

Based on the table above, it can be seen that generally, the strategies of students in the English Department, Universitas Lancang Kuning, Problem Solving Strategies got the highest score (4.11). Based on data obtained by several kinds of strategies that students often use are "I read slowly and carefully to be sure I understand what I am reading $(M=4.31)$ $(\mathrm{SD}=0.73)$, "I try to get back on track or see the other content when I lose concentration" $(M=4.17)$ $(\mathrm{SD}=0.82)$, "When text becomes difficult, I re-read it to increase my understanding" $(\mathrm{M}=4.16)(\mathrm{SD}=85)$.
Besides, the standard deviation score means that all of the respondents' answers are the same or homogenous. It means that Problem Solving Strategies is categorized into High. Therefore, it can be said that most of the students had answered the items in a range of often.

\section{Conclusion}

The result shows that EFL students at the Department of English Education Universitas 
Lancang Kuning already have a strategy to use web content to extend their reading. It can be seen they always and often apply strategies to search for something on the web. Students have a purpose in mind when they want to read online to extend their reading. Besides, the internet has many sources it can help students to get information about reading material. Trung Ngoc Dao (2014) claims With the impact of modern technology and the internet, educators and students have more opportunities to use online reading resources.

Besides, most students also answered frequently using and utilizing enhancements to find needed references such as dictionaries, marking titles, and underlining or circling important information. That means students quickly get the references needed by utilizing strategies. Support by Park \& Kim (2011) found that students employ diverse hypermedia resources (e.g., videos, pictures) and computer applications and functions (e.g., a spell checker, highlighting texts) to facilitate their online reading.

Based on the results obtained, students often use a strategy to find the content needed by entering keywords to connect related information, scroll up down the screen, looking for other content when losing concentration. Support by Elizabeth Schmar Dobler (2003) claims that internet readers have great potential to gather information and almost unlimited as via a link, or an Internet connection, readers can access many sites related to the original idea or search topic needed. Conducted by Guo S (2012) argues that the material available from the internet is precious because it can increase greater interest among teachers and students than the material provided manually. Another reason to use Internet resources in choosing web sites Internet can give readers easy access to a large amount of reading material and the sites provided are also very large, so if we do not find what we need, then sites that are available related to the material we are looking for.

Besides, to make it easier found the content, students often use strategies to change the text contents from a foreign language into a native language to comprehend the text's contents, making it easy to interpret the content needed. Huang et al. (2010) reported that second language online readers predominantly used such support strategies as translation, dictionary consultation, and highlighting.

Then, to understand the text's contents, students must understand the sentence by sentence in a text. The easiest way we have to do is re-read aloud a text to get the text's meaning. Chun (2010) assumes that few studies have investigated language learners' online resources to activate background knowledge during reading. It means, when online content becomes difficult, students should enter the correct keywords and so that online resources available on the web can provide the appropriate content.
New vocabulary is found when reading online on various resources to increase knowledge. Juan PinoSilva (2006) assumes that reading to get the vast vocabulary and other skills needed to read fluently. Ebner and Ehri (2013) assume that those who used aloud thinking protocols in their research to maintain online reader involvement in increasing their vocabulary on the internet found that participatory and independent learning strengthened flexibility when they learned the meaning of words from various online resources.

It is a commonly held belief in the twenty-first century that critical thinking and debate are important skills expected by both young and old generations. (Marpaung et al. 2019). Also, critically reading and evaluating information found can increase intelligence in thinking. Leu et al. (2011) state that evaluating information critically in reading material is an essential aspect of online reading, which involves students' ability to determine a text's accuracy and recognize new information.

Overall, it can be concluded that students use three strategies subscales or factors in reading online. Based on the results obtained, several studies and previous experts support the strategy in this study. Among others, global reading strategies, problem-solving strategies, and support reading strategies. The result, problem-solving strategies dominant EFL students used got from the grand mean score of 4.11 and a standard deviation of 0.98 . The majority of students have a homogenous strategy on extending reading web content. Reading strategies has more significant potential to obtain information and make it easier for students and teachers because online information makes it easier to understand than manual learning.

\section{Recommendation}

Based on data obtained, reading online to develop reading material and the impact of technological development has an excellent opportunity for students to utilize the resources available on the internet. For future researchers, it is recommended to identify the use of strategies in choosing web content in getting reading material".

\section{References}

Chun, D. (2010). CALL technologies for L2 reading post web In N. Arnold \& L. Ducate (Eds.), Present and future promises of CALL: From theory and research to new directions in language teaching (pp. 131-170). San Marcos, TX: CALICO.

Coiro, J. (2003). Exploring literacy on the internet. The Reading Teacher, 56(5), 458-464.

Creswell, J. W. (2012). Educational Research: Planning, Conducting and Evaluating Quantitative and Qualitative Research (4th ed.). USA: Pearson Education, Inc. 
Creswell, J. W. (2014). Research Design: Qualitative, Quantitative, and Mixed Methods Approaches (4th ed.). London: Sage Publications Ltd.

Marpaung, A. P., Yanti, I., \& Marzuki, Y. (2019). Developing Students' Reading Comprehension Using STAD Strategy: A Classroom Action Research at SMA Negeri 7 Pekanbaru. REiLA : Journal of Research and Innovation in Language, 1(1), 10-16. https://doi.org/10.31849/reila.v1i1.2775

Ebner, R. J., \& Ehri, L. C. (2013). Vocabulary learning on the Internet: Using a structured think-aloud procedure. Journal of Adolescent \& Adult Literacy, 56(6), 480-489.

Fountas, I. \& Pinnell, G. (2012). Comprehension Clubs. New York: Scholastic.

Guo, S. (2012). Using authentic materials for extensive reading to promote English proficiency. In English Language Teaching. Retrieved November 25, 2012, fromhttp://www.ccsenet.org/journal/index.php/el t/article/view/18851/12442

Huang, H., Chern, C., \& Lin, C. (2010). EFL learners' use of online reading strategies and comprehension of texts: An exploratory study. Computers \& Education, 52(1), 13-26.

Budianto Hamuddin, B. (2016). Using blog to Promote English Skills for EFL Students: The Students' Perception. Jurnal ELT-Lectura, 3(2), 22-27.

Jusoh and Abdullah (2015), Online Survey of Reading Strategies (OSORS): Students' Online Reading in Academic Context. Malaysian Journal of Distance Education 17(2), 67-81

Leu, D. J., \& Reinking, D. (2010). Final report: Developing Internet comprehension strategies among adolescent students at risk to become dropouts. U.S. Department of Education, Institute of Education Sciences Research Grant.

Leu, D. J., McVerry, J. G., O’Byrne, W. I., Kiili, C., Zawilinski, L., Everett- Cacopardo, H., Kennedy, C., \& Forzani, E. (2011). The new literacies of online reading comprehension: Expanding the literacy and learning curriculum. Journal of Adolescent \& Adult Literacy, 55(1), 5-14.

Nofita, N. S. G., Yudar, R. S., \& Nursafira, M. S. (2019). Exploring Quantity and Diversity of Informal Digital Learning of English (IDLE): A Review of Selected Paper. Utamax: Journal of Ultimate Research and Trends in Education, 1(1), 1-6.
Park, H.-R., \& Kim, D. (2011). Reading-strategy use by English as a second language learners in online reading tasks, Computers \& Education, 57, 2156-2166.

Poole, A., \& Mokhtari, K. (In Press). ESL Students' Use of Reading Strategies When Reading Texts Online and in Print. In K. Mokhtari \& R. Sheorey, R. (Eds.). Studies in First and Second Language Reading Strategies. ChristopherGordon Publishers.

Richards, J. S., and Schmidt, R. (2010). Longman Dictionary of Language and Teaching Applied Linguistics (4th ed.). Great Britain: Pearson Education Limited

Silva, J. P. (2006). Extensive reading through the Internet: Is it worth the while? International Journal of English studies, 9(2), 81-92.

Tabatabaei, M., \& Gui, Y. (2011). The impact of technology on teaching and learning languages. In A. Méndez-Vilas (Ed.) Education in a technological world: communicating current and emerging research and technological efforts (pp. 513- 517). Retrieved from http://www.formatex.info/ict/bo ok/isbncontents.pdf.

The Jakarta Post, (2015). In Indonesia, the number of internet users has reached 73 million people, or 295 of the population. Retrieved from: https://www.thejakartapost.com/news/2015/03/1 0/internet-users-indonesia-reach-73-million.html

Trung Ngoc Dao (Dao, T. N. (2014): Using Internet Resources for Extensive Reading in an EFL Context: Hawaii Pacific University TESOL: Working Paper Series, 12, 72-95. (P.72) 
